\title{
ПРОБЛЕМА БУТТЕВІСНОГО УКОРІНЕННЯ ЛЮДИНИ У ФІЛОСОФІї ПОСТМОДЕРНУ
}

\section{Т.В. Цимбал}

У наш час, коли під впливом локальних «межових ситуацій» та глобальних буттєвісних трансформацій життєві процеси все більше набувають характеру нелінійності та непередбачуваності, зростає варіативність життєвих стратегій та плюралізується стилістика соціокультурного життя людини. Філософи своїм теоретизуванням про бажане, можливе та належне буття намагаються допомогти людині обрати саму себе, організувати власний ціннісний соціокультурний простір, визначитися 3 «системою координат» людськості та людяності, що є підставою для визнання та визначення як актуальної проблеми буттєвісного укорінення людини.

«Укорінення» як проблема і поняття було введене в соціально-філософський дискурс французькою мислителькою ХХ століття Сімоною Вейль (1909-1943). У ході аналізу її однойменної праці з'ясовано, що ідея «вживання» людини в «середину», «гущину» суспільно-політичного буття випливає, по-перше, з реальної ситуації людини 30-40-х років XX століття, їі безальтернативності та невизначеності, ㄲï душевних та фізичних мук від тотального насильства; по-друге, із метафізичної неодностайності стосовно онтологічних альтернатив буття людини, запропонованих есенційно-антропоцентричною та екзистенційно-феноменологічною парадигмами.

Філософські погляди Сімони Вейль були детально розглянуті нами у попередній сатті [9]. Ми намагались показати, що Вейль була однією 3 перших, хто піддав жорсткій критиці «теплохолодність» західно-європейського гуманізму з його ідеалами переважно зовнішнього комфорту, окресливши тим самим контури розуміння буттєвісного укорінення людини, хоча, головним чином, на соціально-політичному рівні.

3 меж критики і оцінки «зарозумілості» раціоналізму, суб'єктивізму сучасної людини народжується і постмодерна парадигма філософського

Актуальні проблеми духовності

(Відп. ред.: Я.В. Шрамко)

Кривий Ріг (2005), 157-163 
розуміння людського буття. Остання є демонстрацією не лише технологічно-прогресивних, але й регресивних тенденцій по відношенню до доби модерну в різних сферах буття, які не забезпечують усю повноту простору для людського екзистування. На грунті цих суперечностей і зростають постмодерні уявлення про неможливість такого підходу до проблем суб'єктивної діяльності та здійнення вільних і відповідальних актів, учинків, які відповідали б певній системі смислів, цінностей, закономірностей, що забезпечують укорінення людини в бутті.

Дійсно, паразитуючий прагматизм, споживацьке суспільство, а також адекватна йому масова культура, локальні конфлікти та глобальні проблеми все більше й більше знекорінюють буття людини, відсторонюючи її від істинних цінностей, вільного, творчого самовиразу, поглиблюючи знекоріненість буття споживача-конформіста, пасивного об'єкта політико-ідеологічного маніпулювання. Духовні абсолюти Істини, Краси і Добра, поняття сущого і належного, в значній мірі, не прийнятні для сучасної людини і сприймаються нею як архаїчні критерії оцінок суспільного, культурного та екзистенційного буття. Тому культура розглядається постмодерном лише як факт залежності свідомості індивіда від соціальних та психофізичних структур, а не феномен, що забезпечує укорінення людини в бутті, оскільки вказані структури існують поза актами людських дій. Як підкреслює З. Бауман, постмодерна доба-то дисбаланс і нестабільність, «Unsicherheit»- «комплексний дискомфорт, що включає в себе, крім відчуття небезпеки, невпененість та незахищеність» людини $[10$, c. 44]. Невизначеність, непевність, ненадійність людського буття - «це не питання вибору, це - доля» сучасної людини [10, с. 154].

Не випадково саме на фоні такої соціально-культурної ситуації, на фоні масової культури у постмодернізмі з'являється гомогенна масовидна суб'єктивність замість ідентичної індивідуальності, соціокультурного суб'єкта. 3 іншого боку, девальвація цінностей та культурно-цивілізаційних установок сучасної людини слугує підставою для поділу світу на цивілізований та нецивілізований. Відповідно, буттєвісне коріння може мати лише людина цивілізованого (постіндустріального) суспільства, незважаючи навіть на те, що зло (війни, агресію) вона може визнавати добром.

Але буттєвісне укорінення експлікується у єдності (діалектиці) життя і буття, представленої у тенденціях до утворення глобальної світової культури, всезагального діалогу культур та збереження етнокультурної самобутності народів. Тобто, йдеться про нескінченність культурного (діяльного) діалогу людини - «творця» і «творіння» як суттєвих характеристик людського «Я», оприявлених у культурі, історії, природі. Подібна іманентна ситуація буття людської самості - бути «незавершеною завершеністю», «локальною глобальністю», передбачає не лише вибір нових можливостей, смислів і цінностей самореалізації особистості, а й відмову 
від колишніх, які заважають втіленню нових у процесі міжлюдської комунікації та призводять до втрати людськості. 3 іншого боку, знекорінення людського буття може відбутися й за умови занадтого перенасичення «Я» всебічними «Ми» (за постмодерністською парадигмою - суб'єктивністю соціальних спільнот), що заважають ідентифікації «Я», призводять до втрати самості, коли індивід перестає бути творцем власного буття і знекорінюється. Таким чином, необмежене зростання можливостей вибору, як ідеал епохи модерну, в постмодерні стає негативним, перетворюючи «індивіда на людину з антенами (з огляду на множинність можливостей та велику кількість цінностей, які йому пропонує сучасне суспільство) на відміну від людини з корінням...» [6, с.14]. За таких обставин людина почувається розгубленою, невизначеною, адже диференціація людського «Я» уможливлюється лише зростанням моральної культури особистості.

У постмодерністській парадигмі, як відомо, відбувається деантропологізація світовідношення і світопізнання, найповніше втілена в лінгвістиці та літературо- і мовознавстві як різновидах гуманітарної культури. А уявлення про елімінацію суб'єкта, врешті-решт, означають зміну уявлень про цінності і смисли культури, зміну уявлень про об'єктивну реальність, історію, тобто, деконструкцію онтології, буття. Постмодерністська методологія ніби «виймає» людину із серцевини буття, життя і культури, позбавляє її біосоціальної субстанційності та спроможності до самозбереження засобом укорінення у світі. Така методологія працює не на індивідуальність, особистість, а на людину-«актора», розчинену в ієрархічних соціальних структурах, на людину-«агента», підпорядковану корпоративним інтересам. Їі буття не налаштоване на цілісність, глобальність, кореневість. Таке несуб'єктне буття насправді є буттям обивателя, для якого найкращий вихід - принципово не визнавати можливості і необхідності впливати на дійсність, змінювати їі. Перетворившись на «позасуб'єктного суб'єкта», людина не здатна на свідому, відповідальну, вільну і творчу діяльність. Цим зумовлене її неоднозначне відношення до цінностей сучасного цивілізованого світу: або їх ігнорування, або зневажання, або прояв консерватизму при появі нових цінностей, що і відбивається на якісній глобальній зміні буття світу, природи, соціуму, культури, на позитивності зрушень у питаннях свободи і відповідальності людини.

Саме ці аспекти буття людини стали предметом сучасних етико-гуманістичних та комунікативних концептів розуміння буття людини як «практичної філософії», головною ідеєю якої є ідея зміни індивідуалізму колективізмом, але таким, що не пригнічує особистість, екзистенціальне існування, не таким, що соціологізує людське життя до рівня «гвинтика» та конформіста, а навпаки, надає можливостей та стимулів для і1ї саморозкриття. Так, у 80-ті роки ХХ століття німецьким мислителем К.О. Апелем запропоноване «останнє обгрунтування» теоретичної та пра- 
ктичної філософії. Підкреслюючи кризу та протиставленість раціоналізму та екзистенціалізму в поглядах на буття людини, суспільства та природи, філософ висуває їх альтернативу - трансцендентальну універсальну прагматику (Див.: [2]). В центрі такого підходу - людське порозуміння зі світом, «Іншим», соціумом, культурою як онтологічною основою істинного буття. У відповідності до останнього, тобто комунікативних актів (порозуміння), інтерсуб'єктивності, онтологічного значення набувають такі етичні цінності, як свобода, суверенність, відповідальність та «етика відповідальності» загалом.

Змістом сучасної комунікативної практичної філософії є проблема узгодження висхідних принципів буття людини у світі з принципами буття самого світу на засадах етики спільної відповідальності, узгодження необхідності, доцільності, мети, цінностей і смислів буття людини і світу, «рівноправності та співпраці різних культур та традицій етносів» [1, с. 355]. Головними завданнями планетарної етики відповідальності є усвідомлення людиною необхідності подолання невідповідності між їі нестримною раціональною діяльністю і «конвенціональною мораллю» та створенням нового нормативно-етичного комплексу відповідальності людини, як гуманістичної засади укорінення людини в бутті. Таким чином, укорінення людини в бутті засобом комунікативних дій передбачає таку скоординованість екзистенціальних та соціальних актів, яка спрямована на досягнення порозуміння на засадах етики відповідальності, цінностей і смислів культури.

Діалогічна «етика відповідальності» Е.Левінаса, як різновид комунікативного дискурсу, грунтується на ідеї, що онтологічна можливість людини бути, сенс її життя та буття взагалі, забезпечуються «буттямдля-Іншого». Звідси, відповідальність та збереження буття набуває ознаки онтологічної, сутнісної ознаки об'єктивної та суб'єктивної реальності, «принципу індивідуації» людського буття, ознакою його обраності, яка «не є привілеєм; це грунтовна характеристика людини як морально відповідальної» істоти (Див.: [5, с. 314]). Філософія Е. Левінаса - найбільш популярна та визнана етична модель сьогодення, бо саме зустріч «Я» та «Іншого» стає сутнісною основою людського буття, а її принципи спростовують обмеження індивідуалізму, егоцентризму та стверджують порозуміння людини зі світом, а значить і їі онтологічну спроможність до буттєвісного укорінення.

Саме тому, на наш погляд, діалогічна етика відповідальності може бути представлена як сучасна альтернативна етико-гуманістична онтологія людського буття, що і повинна стати життєздатною альтернативою прогресизму і безвиході, страху і суб'єктивізму, релігійно-етичній та політико-правовій покорі, постструктуралістському нігілізму і «смерті людини». Таким чином, етика стає основою життя людини, «першою філософією», 
адже в які етичні фарби забарвлена «зустріч Я і Ти»-таким і є життя людей .

Поворот філософії до етичного діалогу людей, окреслений Б. Паскалем, I. Кантом, здійснений Л. Фейєрбахом у XIX столітті та філософією XX століття, був пошуком буттєвісної альтернативи сучасної людини. Однак не рідко абсолютизація «вростання» людини в буття на підставі якоїсь однієї (нехай навіть надто значимої) сторони, сфери людського буття, її «тоталізація» (В. Малахов) призводить до втрати всеохоплюваності погляду на нескінченність можливих соціокультурних практик і світів, втрати об'єктивно-безумовного в бутті людини. Не уникнув такої «тоталізації і Е.Левінас, коли підніс мораль до Єдиного Абсолюту людського буття, хоч сам заперечував подібну «тотальність» будь-якої філософії.

Однак у феноменологічній етиці Е.Левінаса «відповідь-відповідальність» стає онтологічною етично-моральною основою життя людини та у той же час морально-світоглядною цінністю, ввімкненою в духовноемоційне життя людини як феноменологічної суверенності. Тим самим філософ намагається довести недостатню обгрунтованість концепцій буттєвісності етичними основами, вводячи парадоксальне поняття «інакше ніж бути», за допомогою якого робить спробу «врятувати» людську особистісну гідність у буттєвісному ланцюжку: від існування до існуючого, від існуючого до «ншшого». Саме ж існування, за Е. Левінасом, як і за М. Хайдеггером, «одухотворяється першопочатковим онтологічним смислом небуття», «ніщо» $[4$, с. 89$]$.

Сукупний «духовний горизонт» особистості Е.Левінас визначає поняттям суб'єктивного життєвого досвіду у площині інтерсуб'єктивності, що й забезпечить істинну цінність буття людини, буття у відповідності до реальних смислів «транзитивності» існування суб'єкта як нескінченної спроможності виходу за межі данності, досягнутості. Однак, на відміну від класичного екзистенціалізму, Левінас має на увазі зовсім іншу спрямованість людини на світ - не усвідомлення зовнішнього, предметного світу (хоч це і не виключається), а таку цілеспрямованість, яка завершується досвідом відшукання «Іншого», іншої суб'єктивності, «справою людською і виключно людською», досвідом «цінностей», досвідом «захопленості» і «відповідальності» за «Іншого». «Буття-для-себе» як «буття-для-Іншого» та «буття-Іншого» перериває позасмислове буття, а відповідальність стає його первинною, суттєвою, фундаментальною характеристикою, самою структурою буття людини. Отже, буттєвісність людського існування, за Левінасом, конституюється онтологічним принципом «людина-для-людини», «один-заради-Іншого», тим самим заради себе самого. Етичні відношення людей - то їх «саме життя» (Див.: [5]).

Своєрідне бачення проблем людського буття представлене у екзистенціально-феноменологічній герменевтиці М.Фуко. Істинне буття людини, 
за М. Фуко, 一 то «буття-для-себе», оприявлене екзистенціалом «культура себе», в якому підсилений та переоцінений внутрішній зв'язок індивіда 3 самим собою та підвищена значущість відношення до себе. Загальне уявлення про «культуру себе», будучи пов'язаним з екзистенціальним принципом «турботи про себе», своїм змістом має мистецтво впорядкованого існування людини в різноманітних сферах, формах, рівнях та способи творення цілісного горизонту «культурної практики».

Найголовнішим аспектом турботи людини про себе в процесі укорінення в бутті є турбота про власну душу, духовність. Саме в цьому головна відмінність людського буття від існування інших живих істот, непризначених «турбуватися про себе» (Див.: $[8$, с.55]). Адже турбота про себе $\epsilon$ і привілеєм, і обов'язком, дарунком і повинністю людини, що забезпечує свободу, примушує всіх людей удосконалювати свою душу, приймати самих себе як предмет діяльності протягом усього життя. Як зауважував ще Сенека, вчитися все життя - це значить перетворювати своє існування в безперервні вправи, і якщо важливо рано розпочати, то ще важливіше ніколи не розслаблятися (Див.: [7]).

Принцип турботи про себе як спосіб укорінення в бутті творенням «культури себе» містить не лише загальні розмисли про доброчесність та пороки, про щастя та душевні негаразди, але й настанови з приводу того, як себе поводити в тій чи іншій ситуації, як зберегти здоров'я, запобігти фізичним розладам, моральній розпусті та знайти засоби їі «лікування». Творення «культури себе» вимагає від людини визнання недосконалості духу та необхідності його «виправлення», вимагає розуміння, праці й часу, інтерсуб'єктивної практики, як почуття необхідного обов'язку інтенсифікації соціальних відносин, пов'язаних зі «службою душі», всілякими обмінами 3 «Іншим» та системою взаємних зобов'язань людей (Див.: [8, c.61-62]). Соціальний та особистісний зміст практики творення «культури себе», на наш погляд, і буде процесом укорінення людини в бутті, включаючи і різноманітні форми її суб'єктивності: самоусвідомлення, самоаналіз, самовипробування, самооцінку та ін.

Отже, сучасною філософією (а саме постмодерною парадигмою) укорінення людини у бутті передбачалось лише як усвідомлення та вираження суб'єктивно значимих для індивіда можливостей. Але це не відповідає реаліям сучасної соціокультурної ситуації, а звідси - необхідність радикальної зміни ідеалів і цінностей, зростання моральності людини в цілому, яке забезпечується плюралістичністю всіх форм опанування світу та їх пізнавальною рівноправністю. Тим самим на передній ціннісний план у постмодерній парадигмі буття людини виходить ідеал людського порозуміння, комунікації, як буттєвий позитив, що засвідчує особливість становища людини в сучасній соціокультурній ситуації та вимагає вести подальші розвідки проблеми буттєвісного укорінення людини в єдності 
онтологічного, екзистенційно-ціннісного та соціокультурного аспектів.

\section{1 Бібліографія}

[1] Anель K.-О. Етноетика та універсалістська макроетика: суперечність чи доповнювальність: Пер. з нім. // Єрмоленко А.М. Комунікативна практична філософія. - К.: Лібра, 1999. - С. 355-371.

[2] Anель K.-О. Обгрунтування етики відповідальності: Пер. з нім. // Ситниченко Л. Першоджерела комунікативної філософії. - К.: Либідь, 1996. - С. 46-60.

[3] Вейль Сімона. Укорінення. Лист до клірика: Пер. з фр. - К.: «Д.Л.», 1998.

[4] История философии: Запад-Россия-Восток (книга четвёртая: Философия ХХ века) / Под ред. Н.В. Мотрошиловой и А.М.Руткевича. М.: «Греко-латинский кабинет» Ю.А. Шичалина, 1998.

[5] Левінас Е. Філософія, справедливість і любов // Дух і літера.-K.: ФАКТ, 1997. - №1-2. - С. 309-328.

[6] Перотmi A. Виступ на захист полікультурності. - Львів: Кальварія, 2001.

[7] Сенека. Нравственные письма к Луцилию. Трагедии / Пер. с лат. С. Ошерова. - М.: Художественная литература, 1986.

[8] Фуко М. История сексуальности - III: Забота о себе / Пер. с фр.Киев: Дух и литера; Грунт; М.: Рефл-бук, 1998.

[9] Цимбал Т.В. Укорінення людини як головна проблема екзистенціального філософування Сімони Вейль // Актуальні проблеми духовності. - Вип. 4. - Кривий Ріг: Видавництво «I.В.I», 2002. - С. 105-110.

[10] Bauman Z. The Individualized Society. - Cambridge, Polity Press, 2001. 